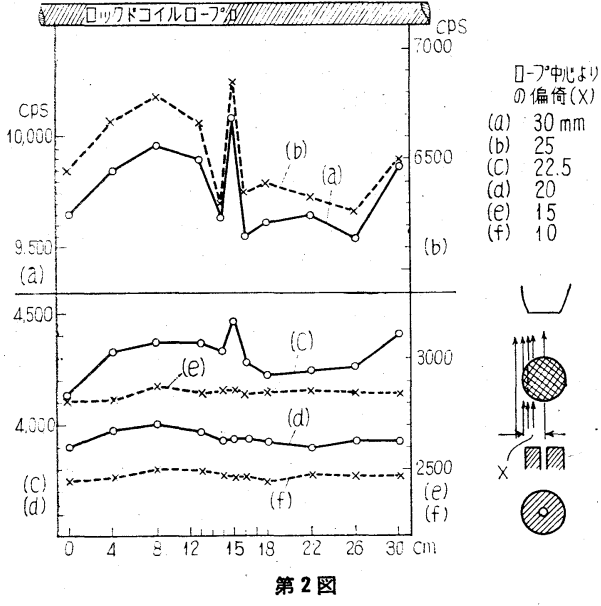

に作られた木製支持台上におく。支持台の中央部におよ そ長さ $40 \mathrm{~cm}$, 幅 $7.0 \mathrm{~cm}$ 程度の空を開け，ロープに下方 より直接 RI を照射できるようにしておく。線源および シンチレーションヘッドの相対的位置を一定に保ち，口 ープの軸方向にこれを移動せしめて透過線を計数した。 第 1 図はその結果で（a）はスリット線源を使用し，キ ズを照射方向に対し直交するように真上に向けた場合，

（b）はスポット線源を使用しキズを真下に向けた場合 で，いずれもキズの位置で計数值が他の位置に比し著る しく増加し，キズを探知し得ることを示した。キズのな い位置で計数值がばらつくのは, ロープのよりの影響, ロープが完全に直線上にないための影響，および計数值 の時間的なばらつきなどの原因によるものである。（a） の場合が( b )の場合よりキズの影響が顕著に表われてい るのは，スッット線源を使用したためにロープのよりの 影響や非直線性の影響が減つたため，またこのキズの大 きさや形状に対しスリット線源が適していることを示し
ている。第 2 図はロープのキズ底面に対しスポット線源 を平行方向に照射せしめた場合で，線源をロープ中心か ら 10，15，20，22.5，25 および $30 \mathrm{~mm}$ それぞれ偏倚 せしめて照射し透過線を計数した結果である。同図によ れば偏倚 $20 \mathrm{~mm}$ まではキズを探知し得ないが $22.5 \mathrm{~mm}$ より探知可能で $25,30 \mathrm{~mm}$ でキズの影響が鋭敏に表わ れている。キズの存在していない位置で計数值が一定值 を示さないが，計数值の不同が測点位置で同様な傾向を 示し, しかも照射偏倚の減少につれ, 不同差も次第に減 少してゆくことはロープ軸が完全に一直線になく僅か蛇 行しているためであることを示している。なおこの場合 についてはオシロ記録測定も行なつた。

以上の実験により上記キズ探知の可能性が明かにされ たのでつぎに直線状ガードシュー上にキズを底にしてロ ープをのせ，シュー側方よりスポット線源を照射せしめ て透過線の計数を行なつた。その結果によればシニーの 肉厚による感度の低下はま妨がれないが，キズの探知は 可能の如くで，キズの底面に接して線源を照射する場合 が最もよい結果を示した。筆者はさらに索道現場におけ る測定を考慮し, 現場測定用の線源およびシンチレーシ ヨンヘッドのホルダーを設計した。

\section{4. むす び}

索道の軌索はガイドシューで受けられている部分が最 も損傷を受けやすいにかかわらず，この部分の検査は一 般に困難で電磁探傷も行ない得ないことを考兄, 筆者は ここにアイソトープによる探傷の基礎的実験を行なつ た。その結果は与えられた大きさのキズがロープの内部 にある場合は比較的探傷しやすいが，ガイドシニ一底面 の接触口ープが摩耗している場合でも, 摩耗の探知はあ る程度可能のようである。筆者はさらに現場測定を容易 にするための線源抢よびシンチレーションヘッドのホル ダーを設計した。なお本実験は関係会社より御援助を得 て行なわれた。嬮く感謝の意を表する次第である。

\title{
2206 干涉計型ガス自動警報器の活用による坑内配電系統の自動しや断
}

\section{資源技術試験所北海道支所唇 中野 貫一(正会員) \\ 資源技術試験所北海道支所第 2 課 ○稲葉千代太}

\section{1. まえがき}

干渉計型ガス自動警報器（以下ガス警報器という）が 資源技術試験所で研究開発され, 実用化の段階を経て種 々な領域に応用されているが，坑内の合理化および機械 化の急速な進展に伴い，ガス対策にもこの概念が取入れ られるようになつて, 従来巡回を主体としたガス管理の

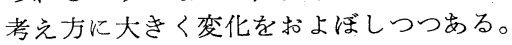

ガス警報器の効用は，a）常時ガスの監視，管理がで きる，b）測定の誤りが少なくなる，c）機械の運転， 監視を安全かつ能率的にする，d）電力の部分括よび全 系統のしや断，制御が容易である等が挙げられ，以上の らちいずれを重く計画に折込むかによつて，それぞれの 目的に応じた種々の利用方式が考えられてくる。このよ 与にガス警報器は, 坑内の保安管理の一端をにならとい ら形で, 從来の管理方式に入り込んでいくものであり, その意味において将来の進展の可能性の分野を大きくも つものであると確信している。
資源技術試験所北海道支所第 2 課

北海道工業開発試験所第 3 部第 2 課

斉藤与四郎(正会員)

中田 三男

筆者らは，早くからこのような構想にもとづいた作業 を精力的に行なつて扣り，今回坑内計装化の一環として， ガス警報器の活用による坑内配電系統の自動しや断を目 的とする一方式を実用化した。この方式は従来の方式と は異なりガス警報器の警報発信と同時にガス警報器と電 源制御装置を接続する電路を無電任とし，同時に坑内配

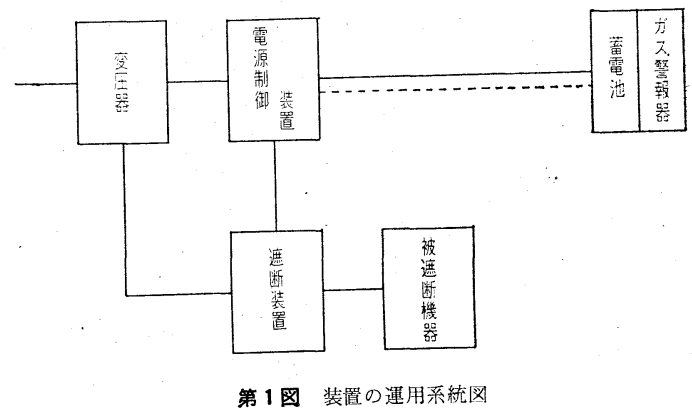

$193\langle 55\rangle$ 


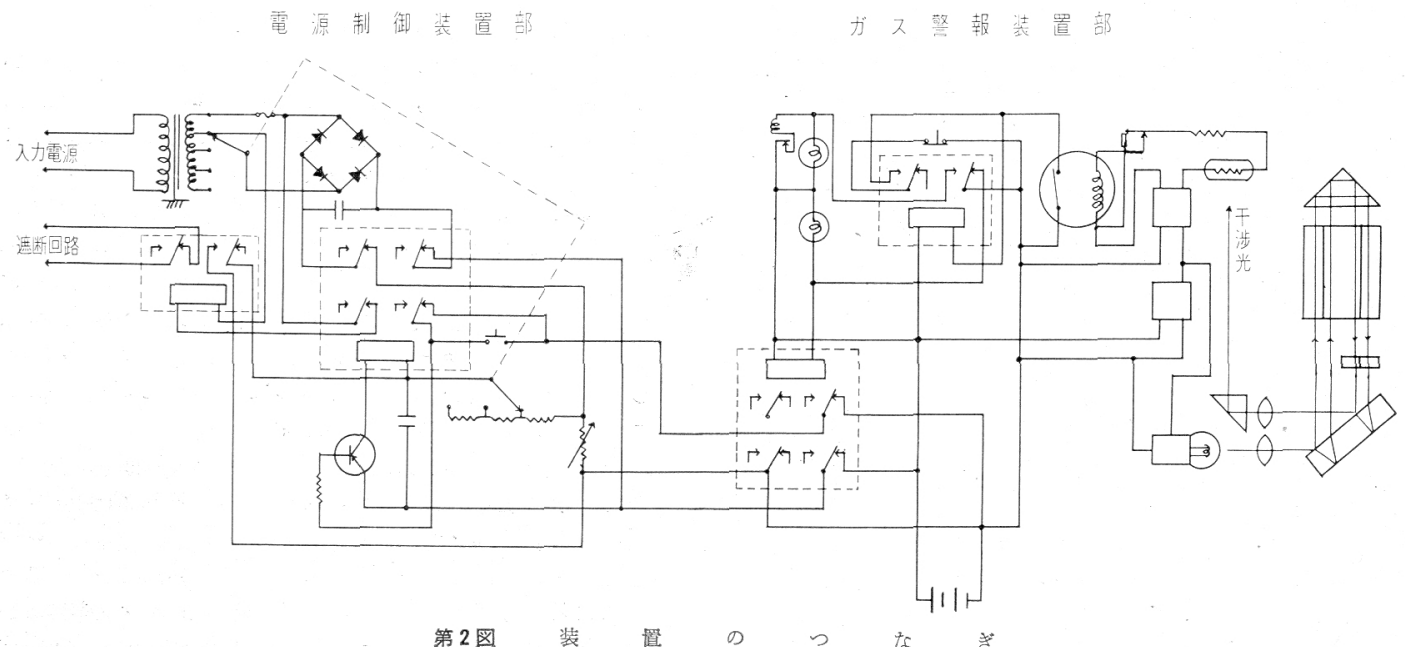

電系統を自動しや断できるなど多くの寸ぐ机た特色をも つている。以下本装置の棈造, 機能などについて報告する

\section{2. 概 要}

今回実用化したガス自動警報器の電源捻よび坑内配電 系統の自動しや断方式の選定については，坑内作業の条 件に対して十分使用できるよう，従来の方式の長所短所 当名含的て

（1）石炭坑内保安規則第 196 条，第 197 条によるガ ス含有率の機器設置制限老受けない。

（2）䉓池の交換がいらない。

（3）設置，移設が容易にできる。

（4）配電系統の自動しや断ができる。

（5）停電等により入力電源の切断にあつても，ガス 警報器の動作が停止しない。

などの点について考虑した。

本装置は保護鉄箱に蓄電池とともに格納されたガス警 報器と, 電源制御装置を導線で接続し, ガスが警報設定 点以下のとき, 電源制御装置の充電回路よりガス警報器 と一体な蓄電㴹㳘電電流を送り, さらにガス警報器よ り電源制御装置に信号を送るための導線の電路を閉じ, ガスが警報設定点以下となつたとさ，警報発信と同時に 導線の電路を開き, 外部しや断装置を動作させるように して, このときでもガス警報器は一体な蓄電池により動 作を連続させるように構成されている。第 1 図は本装置 の運用系統図でめる。

$$
\text { 3. 構成 }
$$

棈成怡前述のようにガス警報装置と電源制御装置より なり、のつなぎ第 2 図に、打の扔の外観を第3 図に示す。

$$
\text { 4. 動作 }
$$

第 3 図により動作を簡単に説明する。ガス警報器に蓄 電池を接続し動作状態とした後, 電源制御装置の拥ボタ ソスイッチを押すと、リレーが動作し充電回路としや断 回路が閉じ，それぞれの電路を動作状態々寸る。

い东，干渉計のチャンバーにガスが侵入すをと，CaS の光電流が減少し, あらかじめ設定された警報点にがス 濃度が達したとき，メーターリレーの接点が閉じ，それ ぞれのリレー回路を動作させて，ランプまたはブザーに

より警報を発し, 同時にガス警報装置と電源制御装置を 接続している接続導線を流れる電路を切断し, スイッチ リレーに接続している配電回路をむしや断する。

\section{5. 諸 特 性}

諸特性乙して，（1）充電特性，（2）温度特性，（3）警 報動作特性について測定した。

\section{$5 \cdot 1$ 充電特性}

入力電源電圧の変動による充電電流抽よび線路抵抗に よる充電電流の変化を測定した。

\section{$5 \cdot 2$ 温度特性}

リレー動作扔よび充電電流の周用温度低存性老求めた

\section{$5 \cdot 3$ 警報動作特性}

ガス警報装置を含めて警報動作の安定性老測定した。

\section{6. むす び}

干渉計型ガス警報器の活用による坑内配電系統の自動 しや断の一方式について述べ，この種方式による坑内配 電回路の設計法を確立した。さらにこの考光方をもとに して試作した装置の坑内現場実験をす含めて諸特性を測 定し,

（1）石崖坑内保安規則第 196 条，第 197 条によるガ ス含有率の機器設置制限を受けない。

（2）電池の交換がいらない。

（3）設置，移設が容易にできる。

（4）配電棌統の自動しや断ができる。

（5）停電等により大力電源の切断に岁つても，ガス 警報器の動作が停止しない。

などの諸条件老満足させ得ることを明らかにした。

坑内に扮けるガス警報器の設置計画は未だ緒についた ばかりであるが，ガス警報器の設置が坑内のガス監視， 管理上不可欠なものとならつつ岁る現在, 本報告がその 参考供されれば幸いでめる。 